\title{
Kadar Kortisol Serum sebagai Indikator Prognosis Sepsis pada Anak
}

\author{
Leny Zabidi, M.Supriatna, Maria Mexitalia \\ Departemen Ilmu Kesehatan Anak FK-UNDIP/ RSUP Dr.Kariadi Semarang
}

Latar belakang. Salah satu respon utama terhadap stres adalah aktivasi aksis hipotalamus-hipofisis-adrenal, diketahui dengan peningkatkan produksi kortisol.

Tujuan. Membuktikan kadar kortisol dapat digunakan sebagai prediktor luaran sepsis.

Metode. Penelitian prospektif, dilakukan di RSUP Dr. Kariadi Semarang. Sepsis didiagnosis menurut Konsensus Konfrensi Sepsis pada Anak tahun 2005, dikelompokkan sebagai luaran perbaikan dan perburukan. Kortisol serum dianalisis dengan metode ELISA. Uji Mann-Whitney U digunakan untuk menganalisis perbedaan kadar kortisol pada luaran sepsis anak. Kadar kortisol dianalisis lebih lanjut menggunakan ROC dan ditentukan titik potong yang optimal.

Hasil. Sejumlah 30 anak dengan diagnosis sepsis diikutsertakan dalam penelitian. Kadar kortisol serum subyek berkisar 64,62 - 836,15 $\mathrm{ng} / \mathrm{mL}$, menunjukkan peningkatan (normal $24-229) \mathrm{ng} / \mathrm{mL}$. Median kadar kortisol pada luaran perbaikan 187,05 $(64,62-509,08)$ $\mathrm{ng} / \mathrm{mL}$ dan pada luaran perburukan $740,91(299,45-836,15) \mathrm{ng} / \mathrm{mL}$. Terdapat perbedaan bermakna kadar kortisol serum pada luaran perbaikan dan luaran perburukan $(\mathrm{p}<0,001)$. Luas area di bawah kurva ROC 0,958, dengan titik potong kadar kortisol $323 \mathrm{ng} / \mathrm{mL}$, RR 48,0 (IK95\%:4,304-535,256; $\mathrm{p}<0,001$ )

Kesimpulan. Kadar serum kortisol lebih dari $323 \mathrm{ng} / \mathrm{mL}$ merupakan prediktor luaran perburukan pada sepsis anak.

Sari Pediatri 2015;17(2):101-6.

Kata kunci. sepsis, kortisol serum, indikator prognosis

\section{Serum Cortisol Level as Prognostic Indicator for Pediatric Sepsis}

\author{
Leny Zabidi, M. Supriatna, Maria Mexitalia
}

Background. One of the major stress response in sepis is the activation of the hypothalamo-pituitary-adrenal axis, which is manifested with with increased cortisol production.

Objective. To determine serum cortisol level as prognostic indicator for pediatric sepsis outcome.

Methods. Prospective study was performed at Dr. Kariadi Hospital Semarang. Sepsis was defined according to the Consensus Conference on Pediatric Sepsis 2005, grouped as good and poor outcome. Serum cortisol level was measured by enzyme-linked immunosorbent assay. Mann-Whitney $U$ test was used to analyze the differences of serum cortisol level in sepsis. Cortisol levels were further analyzed using the ROC to optimal cut-off point.

Results. Thirty pediatric patients with clinical diagnosis of sepsis were enrolled in the study. Serum cortisol level range from 64.62 to $836.15 \mathrm{ng} / \mathrm{mL}$, that showed an increasing level (normal 24 to $229 \mathrm{ng} / \mathrm{mL}$ ). The median serum cortisol level in good outcome was $187,05(64,62-509,08) \mathrm{ng} / \mathrm{mL}$ and for poor outcome was 740,91 $(299,45-836,15) \mathrm{ng} / \mathrm{mL}$. There was significant difference of serum cortisol level in good and poor outcome patients $(\mathrm{p}<0.001)$. The area under the ROC curve was 0.958 , with cut-off point $323 \mathrm{ng} /$ $\mathrm{mL}, \mathrm{RR} 48,0$ ( 95\% CI 4,304- 535,256; $\mathrm{p}<0,001$ ).

Conclusions. Serum cortisol level more than $323 \mathrm{ng} / \mathrm{mL}$ is a good predictor of poor outcome in pediatric sepsis.

Sari Pediatri 2015;17(2):101-6.

Keywords: pediatric sepsis, serum cortisol, prognostic indicator

\footnotetext{
Alamat korespondensi: Dr. Leny Zabidi, Sp.A. RSUD Kab Banjarnegara. Jl. Jendral Sudirman no. 42, Banjarnegara, JATENG. E-mail: leny_ zabidi@idai.or.id
} 


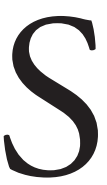
epsis adalah respon sistemik terhadap infeksi yang berat. Insiden sepsis yang meningkat, merupakan penyebab ketiga kematian akibat infeksi. Di Amerika terdapat 570.000 kasus sepsis yang berkunjung ke UGD dan 200.000 kematian akibat sepsis. Sepsis merupakan salah satu penyebab utama morbiditas dan mortalitas pada anak yang dirawat di Pediatric Intensive Care Unit (PICU). Insiden sepsis berat dan syok septik telah meningkat dalam 30-40 tahun terakhir. Di Amerika Serikat diperkirakan sekitar 750.000 kasus baru sepsis berat setiap tahunnya. ${ }^{1,2}$

Sepsis adalah salah satu dari kondisi stres untuk manusia. ${ }^{3}$ Sepsis berat dan syok septik menyebabkan perubahan endokrin yang dapat memengaruhi luaran pasien dengan sepsis. ${ }^{4}$ Salah satu respon terhadap stres adalah aktivasi aksis Hypothalamic-pituitary-adrenal yang ditandai dengan peningkatan produksi kortisol serum. ${ }^{4,5}$ Selama sepsis, mediator inflamasi yang dibawa oleh darah mencapai portal kapiler hipofisis di eminencia mediana melalui arteri hipofise anterior. Sitokin berdifusi ke dalam hipofisis karena area ini bebas dari sawar darah otak, kemudian menuju hipotalamus dan daerah otak tanpa sawar darah otak (lamina terminalis organum vasculosum, organ subfornical, organ subcomissura, area postrema, kelenjar pineal dan pleksus koroidalis). Disamping itu, sel glia dapat menghasilkan sejumlah sitokin, seperti IL-1, IL-2, dan IL-6 yang akan menambah sitokin yang beredar dalam darah. ${ }^{3}$

Kortisol adalah hormon glukokortikoid yang dihasilkan oleh kelenjar adrenal. ${ }^{3}$ Kortisol memiliki peran penting dalam memelihara tonus vaskular, integritas endotel, permebilitas vaskular, dan distribusi cairan tubuh di dalam vaskular, dan juga potensiasi aksi vasokonstriktor dari katekolamin. ${ }^{5}$ Produksi harian dari kortisol adalah $55 \mu \mathrm{mol} / \mathrm{L}$ (laki-laki) dan $44 \mu \mathrm{mol} / \mathrm{L}$ (perempuan) dengan kadar teringgi pada pagi hari. ${ }^{3}$ Dalam plasma, kortisol dibawa oleh globulin pengikat kortisol dengan kapasitas $22 \mu \mathrm{g} / \mathrm{dL}$ hingga $25 \mu \mathrm{g} / \mathrm{dL}$. Ketika kadar kortisol meningkat, kortisol diikat oleh albumin dan fraksi bebas akan meningkat, pada tingkat jaringan kortisol diikat oleh reseptor di sitoplasma. ${ }^{3}$

Beberapa studi terhadap sepsis berat dan syok septik metunjukkan bahwa kadar kortisol tinggi memiliki prognosis yang buruk. Kwon $\mathrm{dkk}^{5}$ menyimpulkan bahwa kadar kortisol serum yang tinggi $(\geq 30 \mu \mathrm{g} / \mathrm{dL})$ berhubungan secara bermakna dengan angka kematian selama perawatan di rumah sakit. Bendel $\mathrm{dkk}^{4}$ yang meneliti pasien sepsis dan syok septik mendapatkan bahwa kortisol bebas dan kortisol total pada kelompok non survive lebih tinggi dibandingkan kelompok survive.

Berdasarkan latar belakang tersebut penulis mengadakan penelitian untuk mengetahui apakah kadar kortisol dapat digunakan sebagai indikator prognosis sepsis pada anak.

\section{Metode}

Penelitian ini menggunakan rancang bangun studi kohort prospektif, dilakukan di ruang perawatan anak (HCU dan PICU) RSUP Dr. Kariadi Semarang pada periode September 2012 - Februari 2013. Populasi target adalah anak sepsis dan populasi terjangkau adalah anak dengan sepsis. Sampel penelitian ini adalah populasi terjangkau yang memenuhi kriteria inklusi. Kriteria inklusi adalah usia 2 bulan-13 tahun, orang tua menyetujui ikut dalam penelitian, dan pengambilan darah dilakukan segera sejak diagnosis sepsis ditegakkan. Kriteria eksklusi adalah adanya adrenal insufisiensi primer, hiperplasi adrenal kongenital, kelainan kongental multipel, dan gizi buruk.

Pengambilan sampel dengan cara consecutive sampling sampai besar sampel terpenuhi. Subyek penelitian dinilai skor PELOD saat awal (hari ke-1 diagnosis sepsis ditegakkan). Penilaian skor PELOD untuk menilai luaran sepsis dilakukan oleh peneliti dengan dibantu oleh dokter yang bertugas di PICU dan HCU. Pengukuran tiga kali, yaitu pada hari ke-1, ke-3, dan ke-6 sejak diagnosis sepsis ditegakkan. Nilai skor PELOD ditentukan oleh peneliti. Pemeriksaan klinis meliputi derajat kesadaran, reaksi pupil, frekuensi jantung, dan tekanan darah. Pemeriksaan laboratorium yang dilakukan adalah kadar kortisol serum (dilakukan pada pagi hari pukul 8-9 pagi dengan volume darah $3 \mathrm{cc}$ ), jumlah leukosit dan trombosit, SGOT dan kreatinin, protrombine time, dan analisis gas darah. Metode ELISA digunakan untuk pemeriksaan kadar kortisol serum dan dilakukan di Laboratorium GAKY FK UNDIP /RSUP Dr. Kariadi Semarang. Pemeriksaan kultur darah, urin maupun sekret endotracheal tube (ET) dan dapat menunjukkan hasil positif maupun negatif.

Luaran sepsis dibedakan dua, yaitu perbaikan dan perburukan. Dikatakan perbaikan apabila 
pada hari ke-6 terjadi perubahan ke arah membaik pada gejala klinis maupun laboratorium dan tidak didapatkan tanda gagal organ. Perbaikan ditentukan dengan adanya penurunan skor PELOD pada hari ke-1 saat diagnosis sepsis ditegakkan dibandingkan dengan hari ke-6 setelah diagnosis sepsis ditegakkan. Perburukan ditentukan apabila terjadi perubahan ke arah memburuk pada gejala klinis maupun laboratorium. Hal ini ditandai dengan peningkatan skor PELOD pada hari ke-1 saat diagnosis sepsis ditegakkan dibandingkan hari ke-6 atau hari ke-3. Perburukan juga ditentukan apabila pasien meninggal sebelum hari ke-6, atau berlanjut menjadi sepsis berat dengan ditandai disfungsi organ atau meninggal. Skor PELOD dihitung berdasarkan hasil pemeriksaan dan perhitungan menggunakan sistem skor PELOD. ${ }^{38}$

Semua data penelitian dicatat dalam formulir yang telah disediakan untuk penelitian, Setelah data terkumpul, terlebih dahulu diperiksa kelengkapan data dan kebenarannya. Selanjutnya, data diberi kode dan ditabulasi dan dimasukkan ke dalam komputer. Didapatkan distribusi data yang tidak normal dengan nilai $\mathrm{p}=0,014$ maka digunakan uji Mann-Whitney $\mathrm{U}$ untuk menganalisis perbedaan kadar kortisol serum pada luaran sepsis.

Analisis kurva ROC dilakukan untuk mengetahui apakah kadar kortisol serum dapat dipergunakan sebagai indikator prognosis luaran sepsis. Didapatkan luas area di bawah kurva $\geq 0,7$ maka kadar kortisol serum saat diagnosis sepsis ditegakkan dianggap dapat dipergunakan sebagai indikator prognosis. Selanjutnya, akan ditentukan nilai cut-off-point kadar kortisol yang dapat dipergunakan sebagai indikator prognosis luaran sepsis dan akan dinilai akurasi dari kadar kortisol berdasarkan nilai cut-off-point sebagai indikator. Setelah kadar kortisol dikategorikan sesuai dengan nilai cut-off-point, maka kadar kortisol >cut-off point ditentukan sebagai faktor risiko untuk terjadinya luaran perburukan. Setelah itu, dilanjutkan analisis untuk menentukan risiko luaran perburukan pada sepsis, yang dinyatakan sebagai risiko relatif (RR). Uji statistik dianggap bermakna apabila nilai $\mathrm{p} \leq 0,05$, rentang interval kepercayaan ditetapkan $95 \%$.

\section{Hasil}

Selama periode penelitian didapatkan 30 anak yang dirawat di HCU dan PICU yang sesuai dengan kriteria penelitian. Karakteristik subyek penelitian tertera pada Tabel 1.

Sebagian besar subyek penelitian adalah laki-laki, 20 (67\%) anak. Rerata umur subyek penelitian adalah 41,7 bulan (2-144) bulan. Tidak terdapat perbedaan yang bermakna antara kelompok subyek dengan skor PELOD awal $<20$ dan awal $>20$ dalam hal jenis kelamin, usia, status gizi maupun penyakit dasar dengan nilai $p>0,05$. Hal tersebut menunjukkan bahwa subyek homogen sehingga faktor jenis kelamin, usia, status gizi dan penyakit dasar tidak memengaruhi luaran sepsis pada masing-masing kelompok. Dari 30 subyek, diagnosis terbanyak didapatkan bronkhopneumonia $(20 \%)$ dan meningoensefalitis (20\%), selanjutnya pasca laparatomi, pasca status konvulsivus, dan diare akut dehidrasi berat masing-masing $7 \%$.

Tabel 1. Karakteristik subyek penelitian $(\mathrm{n}=30)$

\begin{tabular}{lccc}
\hline Karakteristik & $\begin{array}{c}\text { Sepsis } \\
(\mathrm{n}=23)\end{array}$ & $\begin{array}{c}\text { Sepsis berat } \\
(\mathrm{n}=7)\end{array}$ & $\mathrm{p}$ \\
\hline Jenis kelamin & & & \\
$\quad$ Laki-laki & 16 & 4 & 0,542 \\
$\quad \begin{array}{l}\text { Perempuan } \\
\text { Umur (bulan) }\end{array}$ & $74,3 \pm 33,62$ & $66 \pm 59,27$ & 0,81 \\
$\begin{array}{l}\text { Status gizi } \\
\text { Baik }\end{array}$ & 15 & 5 & 0,760 \\
$\quad$ Kurang & 8 & 2 & \\
$\begin{array}{l}\text { Penyakit dasar } \\
\quad \text { Non bedah }\end{array}$ & 18 & 5 & 0,708 \\
$\quad$ Bedah & 5 & 2 & \\
\hline Keterangan $=$ sepsis: Skor PELOD awal <20, Sepsis berat : Skor PELOD \\
awal $\geq 20$
\end{tabular}

Tabel 2. Kadar kortisol serum dan luaran sepsis

\begin{tabular}{|c|c|c|c|c|c|}
\hline \multirow{2}{*}{ Kortisol serum (ng/mL) } & \multicolumn{2}{|c|}{ Luaran sepsis } & \multirow{2}{*}{$\mathrm{RR}$} & \multirow{2}{*}{ IK95\% } & \multirow[b]{2}{*}{$\mathrm{p}$} \\
\hline & Perburukan & Perbaikan & & & \\
\hline$>323$ & 8 & 3 & 48,0 & $4,304-535,256$ & 0,0001 \\
\hline$\leq 323$ & 1 & 18 & & & \\
\hline Jumlah & 9 & 21 & & & \\
\hline
\end{tabular}


Kadar kortisol serum pada 30 subyek memiliki rentang 64,62-836,15 ng/mL dengan median 225,47 $\mathrm{ng} / \mathrm{mL}$. Sementara luaran sepsis didapatkan $21(70 \%)$ subyek mengalami perbaikan dan 9 (30\%) perburukan. Berdasarkan luaran sepsis setelah evaluasi hari ke-6 perawatan, kadar kortisol serum perbaikan adalah $187,05(64,62-509,08)$ dan perburukan 740,91 $(299,45-836,15)$ dengan $\mathrm{p}=0,0001$. Median kadar kortisol pada luaran perburukan adalah $740,91 \mathrm{ng} / \mathrm{mL}$ dengan nilai minimum 299, $45 \mathrm{ng} / \mathrm{mL}$ dan maksimum $836,15 \mathrm{ng} / \mathrm{mL}$. Perbedaan rerata kadar kortisol pada anak sepsis dengan luaran perbaikan dan perburukan dianalisis dengan uji Mann-Whitney U. Didapatkan rerata kadar kortisol serum pada kelompok luaran perburukan lebih tinggi secara bermakna dibanding kelompok luaran perbaikan ( $\mathrm{p}<0,001)$.

Analisis ROC kortisol serum sebagai indikator prognostik luaran sepsis pada anak tertera pada Gambar 1. Hasil analisis ROC pada Gambar 1 menunjukkan luas area di bawah kurva ROC $>0,7$ adalah 0,958 . Hal tersebut menunjukkan bahwa kadar kortisol dapat digunakan sebagai indikator prognostik luaran sepsis pada anak. Hasil analisis ROC juga menunjukkan nilai p yang bermakna $(\mathrm{p}<0,01)$. Nilai cut-off point untuk kadar kortisol serum adalah $323 \mathrm{ng} / \mathrm{mL}$. Selanjutnya, dilakukan analisis untuk menentukan nilai risiko relatif

\section{ROC Curve}

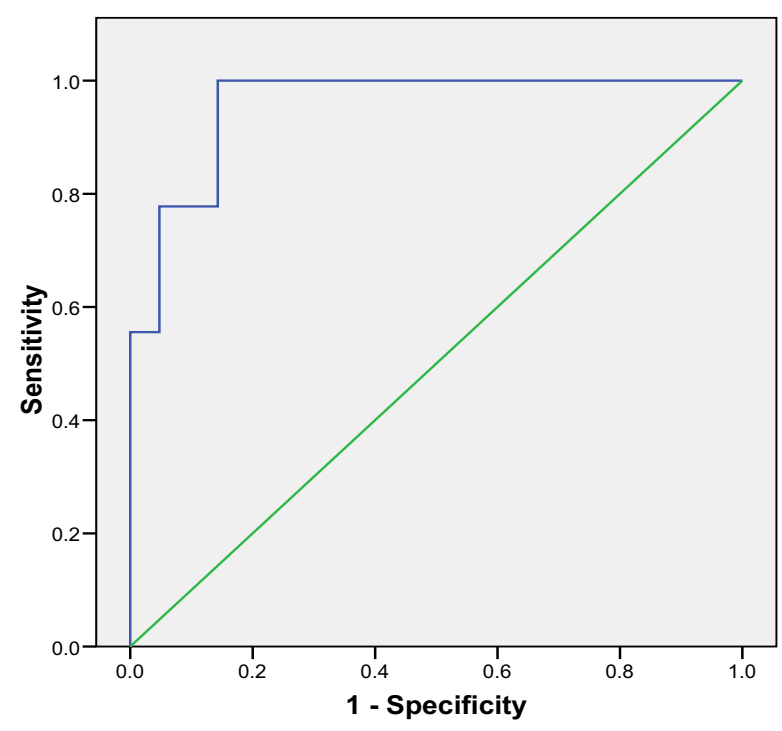

Gambar 1. Kurva ROC kortisol serum sebagai indikator prognosis luaran sepsis pada anak kadar kortisol $>323 \mathrm{ng} / \mathrm{mL}$ terhadap luaran sepsis seperti tertera pada Tabel 2 .

Didapatkan RR 48,0 (IK95\%:4,304-35,256 ) dengan nilai $\mathrm{p}<0,0001$. Hal ini menunjukkan bahwa kadar kortisol $>323 \mathrm{ng} / \mathrm{mL}$ dapat meningkatkan risiko luaran perburukan 48 kali.

\section{Pembahasan}

Persentase subyek penelitian kami terdiri atas $67 \%$ laki-laki dan 37\% perempuan, dengan penyakit dasar terbanyak adalah non-bedah yaitu meningoensefalitis (20\%) dan bronkhopneumonia (20\%). Waston $\mathrm{dkk}^{6}$ melaporkan insiden sepsis lebih tinggi pada laki-laki $(54,8 \%)$ dibandingkan perempuan $(45,2 \%)$ pada kelompok usia 1-9 tahun dengan penyakit dasar terbanyak adalah penyakit neuromuskular $(24,7 \%)$. Wolfler $\mathrm{dkk}^{7}$ melaporkan insiden sepsis 59\% pada anak laki-laki dengan rerata usia 39 bulan dan penyakit dasar terbanyak adalah infeksi saluran pernapasan $(47,2 \%)$. Sementara itu, Lodha $\mathrm{dkk}^{8}$ melaporkan pasien dengan penyakit yang mendasari, yaitu infeksi neurologis, kardiovaskular, dan pulmonologi menempati urutan tertinggi penderita sepsis yang dirawat.

Kami mendapatkan $60 \%$ kultur positif dengan kuman patogen terbanyak Klebsiella pneumonia pada kultur darah, Acinetobacter baumanii pada kultur cairan, Endotracheal tube dan Eschericia coli pada kultur urin. Didapatkan pula $66 \%$ dari pasien dengan hasil kultur positif memiliki luaran perburukan selama perawatan. Wofler ${ }^{7} \mathrm{dkk}$ melaporkan hasil kultur positif 56,2\% dengan patogen terbanyak adalah Pneumococcus, Pseudomonas aeruginosa, dan Staphylococcus aureus. Demikian pula Waston $\mathrm{dkk}^{6}$ melaporkan Staphylococcus sebagai patogen terbanyak diikuti Streptococcus dan Pseudomonas, serta mortalitas tertinggi didapatkan pada anak dengan infeksi Pneumococcus (14,5\%) dan infeksi jamur (13,0\%).

Selama sepsis, aktivasi aksis HPA ditandai dengan peningkatan pelepasan kortikotropin dari kelenjar hipofise yaitu peningkatan sekresi adrenal dan kadar kortisol yang tinggi dan merupakan komponen penting dari adaptasi umum terhadap stres. ${ }^{9}$ Kortisol memiliki peran penting dalam menjaga tonus pembuluh darah, integritas endotel, permeabilitas vaskular, dan distribusi cairan tubuh dalam kompartemen vaskular. ${ }^{5}$ Kami mendapatkan kadar kortisol serum dengan rentang $(64,62-836,15) \mathrm{ng} / \mathrm{mL}$ dengan median kadar kortisol 
serum 225,47 ng/mL. Sarthi dkk ${ }^{10}$ mendapatkan kadar kortisol basal pada anak dengan sepsis 24,5 sampai dengan $269,5 \mu \mathrm{g} / \mathrm{dL}(245-2695) \mathrm{ng} / \mathrm{mL}$. Kadar kortisol dengan rentang yang cukup luas dapat dimungkinkan karena jumlah subyek yang sedikit dengan derajat sepsis yang tidak sama.

Kami mendapatkan median kadar kortisol pada luaran perbaikan $187,05(64,62-509,08) \mathrm{ng} / \mathrm{mL}$, sedangkan pada kelompok luaran perburukan 740,91 $(299,45-836,15) \mathrm{ng} / \mathrm{mL}$. Terdapat perbedaan rerata kadar kortisol antara kelompok luaran perbaikan dan perburukan. Rerata kadar kortisol pada kelompok luaran perburukan lebih tinggi dibandingkan perbaikan. Pileri $\mathrm{dkk}^{11}$ melaporkan kadar kortisol serum lebih tinggi pada kelompok nonsurvivor dibandingkan survivor maupun pasien nonsepsis. Sebaliknya, menurut laporan Sarthi $\mathrm{dkk}^{10}$ tidak terdapat perbedaan kadar kortisol pada kelompok survival dan nonsurvival dengan rentang kadar

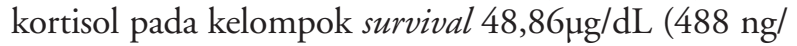
$\mathrm{mL})-81,71 \mu \mathrm{g} / \mathrm{dL}(817,1 \mathrm{ng} / \mathrm{mL})$, sedangkan pada kelompok nonsurvival $40,21 \mu \mathrm{g} / \mathrm{dL}(402,1 \mathrm{ng} / \mathrm{mL})$ $121,82 \mu \mathrm{g} / \mathrm{dL}(1218,2 \mathrm{ng} / \mathrm{mL})$.

Penelitian yang dilakukan oleh Sam dkk, ${ }^{12}$ pada pasien sepsis dewasa, melaporkan bahwa kadar kortisol meningkat pada sebagian besar pasien dengan septis dan kadar kortisol $\geq 1242 \mathrm{nmol} / \mathrm{L}(450 \mathrm{ng} / \mathrm{mL})$ berhubungan dengan mortalitas yang tinggi. Demikian pula penelitian yang dilakukan oleh Christ-Crain $\mathrm{dkk}^{13}$ melaporkan bahwa kadar kortisol adalah prediktor derajat keparahan dan luaran pada community-acquired pneumonia (CAP) pada pasien dewasa dengan luas area di bawah kurva ROC 0,76 (IK95\% = 0,70-0,81) dan cut-off point optimal sebesar $960 \mathrm{nmol} / \mathrm{L}(347,5 \mathrm{ng} /$ $\mathrm{mL}$ ). Sesuai dengan penelitian kami yang mendapatkan bahwa kadar kortisol serum dapat digunakan sebagai indikator prognostik luaran sepsis, dengan luas area di bawah kurva ROC $>0,7$ adalah 0,958. Kadar kortisol $>323 \mathrm{ng} / \mathrm{mL}$ dapat meningkatkan risiko terjadinya luaran perburukan 48 kali dengan.

Keterbatasan penelitian kami adalah jumlah subyek yang sedikit sehingga didapatkan rentang kadar kortisol yang cukup luas. Pada subyek dengan penyakit dasar penyakit susunan saraf pusat (meningoencefalitis) tetap mendapatkan kortikosteroid yang merupakan salah satu terapi medikamentosa pada penyakit tersebut, tetapi kortikosteroid yang diberikan tidak dalam dosis tinggi dan diberikan dalam waktu yang pendek (3 hari pemberian). Semakin tinggi dosis dan semakin lama pemberian kortikosteroid merupakan prediktor terjadinya supresi terhadap fungsi hipothalamushipofise- adrenal. ${ }^{9}$

\section{Kesimpulan}

Kadar kortisol serum dapat digunakan sebagai indikator prognosis anak dengan sepsis. Terdapat perbedaan antara kadar kortisol serum pada anak sepsis dengan luaran perbaikan dan perburukan. Kadar kortisol $>323 \mathrm{ng} / \mathrm{mL}$ terbukti meningkatkan risiko luaran perburukan sepsis pada anak.

\section{Daftar pustaka}

1. Bone RC, Grodzin CJ, Balk RA. Sepsis: a new hypothesis for pathogenesis of the disease process. Chest 1997;112 :235-43.

2. Guidet B, Aegerter P, Gauzit R, Meshaka P, Dreyfuss D. Incidence and impact of organ dysfunctions associated with sepsis. Chest 2005;127:942-951.

3. Maxime V, Siami S, Annane D. Metabolism modulators in sepsis: the abnormal pituitary response. Crit Care Med 2007;35:S596-601.

4. Bendel S, Karlsson S, Pettila V, Loisa P, Varpula M, Ruokonen E. Free cortisol in sepsis and septic shock. Anesth Analg 2008;106:1813-9.

5. Kwon YS, Suh GY, Kang EH, Koh WJ, Chung MP, Kim $\mathrm{H}$, dkk. Basal serum cortisol levels are not predictive of response to corticotropin but have prognostic significance in patients with septic shock. J Korean Med Sci 2007;22 :470-5.

6. Waston RS, Carcillo JA. Scope and epidemiology of pediatric sepsis. Pediatr Crit Care Med 2005;6:S3-5.

7. Wolfler A,Silvani P, Musicco M, Antonelli M, Salvo I. Incidence af and mortality due to sepsis, severe sepsis and septic shock in Italian Pediatric Intensive Care Units : a prospective national survey. Intensive Care Med 2008;34:1690-7.

8. Lodha R, Vivekanandhan S, Sarthi M, Arun S, Kabra $S$. Thyroid function in children with sepsis and septic shock. Acta Peadiatrica 2007;96:406-9.

9. Annane D, Sebille V, Troche G, Raphael JC, Gajdos P, Bellissant E. A 3-level prognostic classification in septic shock based on cortisol levels and cortisol response to corticotropin. JAMA 2000;283:1038-45.

10. Sarthi M, Lodha R, Vivekanandhan S, Arora NK. Adrenal status in children with septic shock using 
low-dose stimulation test. Pediatr Crit Care Med 2007;8:1-6.

11. Pileri D, Accardo-Palumbo A, D'Amelio L, D'Arpa N, Arnone G,Grisaffi C, dkk. Serum levels of cortisol, immunoglobulin, and C-reactive protein in burn patients. Ann Burns Fire Disasters 2009;22:3-5.

12. Sam S, Corbridget TC, Mokhlesi B, Comellas AP,
Molitch ME. Cortisol levels and mortality in severe sepsis. Clin Endocrinol 2004;60:29-35.

13. Christ-Crain M, Stolz D, Julta S, Couppis O, Muller $\mathrm{C}$, Bingisser R, dkk. Free and total cortisol levels as predictors of severity and outcome in communityacquired pneumonia. Am J Respir Crit Care Med 2007;176:913-20. 